\title{
SPOŁECZNA ODPOWIEDZIALNOŚĆ BIZNESU - POMIĘDZY ALTRUIZMEM A EGOIZMEM PRZEDSIĘBIORSTW
}

Jeśli chcesz zmienić swiat, zrób to za pośrednictwem biznesu, a jeśli pragniesz poprawić wyniki swojej dziatalności biznesowej, pomóż zmienić świat.

Steve Hilton

\section{WSTĘP}

Idea społecznej odpowiedzialności biznesu (ang. Corporate Social Responsibility, w skrócie CSR) ${ }^{1}$ - choć nienowa i szeroko dyskutowana na forach ekonomiczno-społecznych - wciąż wzbudza wiele kontrowersji, zarówno w kwestiach teoretycznych, jak i praktycznych. Istotą tego sporu są rozważania na temat współczesnych celów i funkcji przedsiębiorstwa oraz fundamentalne pytanie o to, czy biznes w ogóle powinien zajmować się sprawami społecznymi.

$\mathrm{Z}$ jednej strony znamienne jest czysto filantropijne podejście A. Carnegie'ego ${ }^{2}$, który, tworząc podwaliny koncepcji społecznej odpowiedzialności biznesu, określił ją jako moralny obowiązek i „osobisty wkład właściciela przedsiębiorstwa w poprawę kondycji społeczeństwa, kierując się zasadą dobroczynności i zasadą

${ }^{1}$ Społeczna odpowiedzialność biznesu w literaturze przedmiotu zwana jest również społeczną odpowiedzialnością przedsiębiorstw, biznesem społecznie odpowiedzialnym czy (z angielskiego) ideą CSR, a także etycznym biznesem lub biznesem moralnym. W dalszej części artykułu pojęcia te stosowane będą zamiennie.

${ }^{2}$ A. Carnegie stworzył teoretyczne podwaliny klasycznego ujęcia idei społecznej odpowiedzialności biznesu w książce wydanej w 1889 r., zatytułowanej Ewangelia bogactwa (ang. The Gospel of Wealth). 
powierniczości” ${ }^{3}$ Skrajnie odmienne stanowisko prezentował zaś M. Friedman, nazywając ideę CSR „dogłębnie wywrotową doktryną" i dowodząc, iż obowiązkiem oraz najwyższym celem każdego przedsiębiorstwa (komercyjnego) jest maksymalizacja zysku, a nie rozwiązywanie problemów społecznych. Poglądy te podzielał także M. Wolf - dziennikarz „Financial Times”, który pisał, że „celem dobrych firm jest podnoszenie zysku, a nie ratowanie planety. Pozwólmy im [przedsiębiorstwom] nie mieszać tych dwóch funkcji”’

Ekstremalne różnice w prezentowanych powyżej postawach wobec koncepcji społecznej odpowiedzialności biznesu, wątpliwości o słuszność przytoczonych wypowiedzi, a także wewnętrzne przekonanie o tym, że pomiędzy zabójczym dla przedsiębiorstw altruizmem a równie niebezpiecznym, czystym egoizmem biznesu istnieje złoty środek, zainspirowały autorkę do napisania niniejszego artykułu. Jego celem jest ukazanie współczesnej idei CSR jako strategii umożliwiającej wzrost konkurencyjności przedsiębiorstw oraz realizację i wzmacnianie ich ekonomicznych funkcji (zgodnie z postulatami M. Friedmana), przy jednoczesnym zaangażowaniu biznesu w sprawy społeczne (tak, jak życzyłby tego sobie A. Carnegie). Innymi słowy, odnosząc się do cytowanej powyżej wypowiedzi M. Wolfa, zamierzeniem autorki jest wykazanie, iż firmy mogą poprawiać swoje wyniki finansowe nie tylko dzięki działaniom stricte ekonomicznym, ale również poprzez udział w przedsięwzięciach „ratujących planetę”, a „mieszanie” funkcji ekonomicznych ze społecznymi może dawać efekt synergiczny.

Zadeklarowanemu celowi podporządkowany został układ niniejszej pracy, obejmujący rozszerzoną definicję społecznej odpowiedzialności przedsiębiorstw, obszary i typy tej odpowiedzialności, opis korzyści wynikających ze stosowania strategii CSR, zarówno dla interesariuszy (ang. stakeholders) ${ }^{6}$, jak i samej firmy, oraz zagrożenia wynikające $\mathrm{z}$ wypaczania idei CSR.

${ }^{3}$ M. Bojar, Spoteczna odpowiedzialnośc przedsiębiorstw - wybrane aspekty, [w:] M. Bojar (red.), Spoteczna odporwiedzialność w biznesie, Wydawnictwo Politechniki Lubelskiej, Lublin 2007, s. 13.

${ }^{4}$ Cyt. za: M. Bojar, op. cit., s. 13.

${ }^{5}$ Cyt. za: A. Lewicka-Strzałecka, Odpowiedzialność moralna w życiu gospodarczym, IFiS PAN, Warszawa 2006, s. 22.

${ }^{6} \mathrm{~W}$ niniejszym artykule interesariusze rozumiani są bardzo szeroko. Zalicza się do nich m.in.: właścicieli przedsiębiorstwa, menedżerów, innych pracowników, dostawców, klientów, konkurentów, instytucje finansowe, instytucje rządowe i pozarządowe, społeczność lokalną i regionalną oraz wszelkie inne podmioty mające obecnie (lub mogące mieć w przyszłości) określony wpływ na firmę. Zapoznaj się także z teorią interesariuszy. 


\section{POJĘCIE SPOŁECZNEJ ODPOWIEDZIALNOŚCI BIZNESU}

Społeczna odpowiedzialność biznesu jest w swej definicji koncepcją wysoce złożoną i niejednorodną, a przez to trudną do sprecyzowania i jednoznacznej interpretacji. Literatura przedmiotu oferuje coraz to nowsze ujęcia idei CSR zarówno w wąskim, jak i szerokim znaczeniu, niemniej jednak szybka ewolucja biznesu społecznie odpowiedzialnego w praktyce sprawia, że koncepcja ta wciąż wymyka się poza ciasne ramy książkowych definicji. Zadanie jednolitego określenia pojęcia społecznej odpowiedzialności przedsiębiorstw utrudnia także fakt, że w zależności od podmiotu definiującego (np. etyk, ekonomista teoretyk czy menedżer) różnie rozkładane są akcenty pomiędzy społecznym a ekonomicznym wymiarem idei CSR, jak również inaczej ujmowany jest przedmiot i zakres odpowiedzialności.

$Z$ jednej strony, wciąż żywe jest klasyczne, wręcz altruistyczne ujęcie koncepcji społecznej odpowiedzialności biznesu autorstwa A. Carnegie'ego, zgodnie z którym społeczne zaangażowanie firm wynika $z$ poczucia ich moralnej powinności, potrzeby dzielenia się z innymi oraz zasady dobroczynności i powierniczości ${ }^{7}$. Stanowisko to podzielane jest także przez F. P. Seitela, który dodatkowo wzbogacił definicję CSR, nadając tej idei status normy społecznej i wiążąc ją ze ściśle etycznym postępowaniem przedsiębiorstw ${ }^{8}$. Znamienne, iż w tak rozumianej koncepcji społecznej odpowiedzialności biznesu tylko bezinteresowność jest gwarancją czystości działań firmy, a pytanie o opłacalność filantropii czy o jakikolwiek ekonomiczny wymiar CSR jest nieeleganckie, a nawet niemoralne. Nieco mniej rygorystyczne, choć też prospołeczne, ujęcie odpowiedzialności przedsiębiorstw prezentowane jest przez Światową Radę Biznesu na rzecz Zrównoważonego Rozwoju, która przyjmuje, że społeczna odpowiedzialność jest „zobowiązaniem biznesu do przyczyniania się do zrównoważonego rozwoju ekonomicznego poprzez pracę z zatrudnionymi i ich rodzinami, społecznością lokalną oraz społecznością jako całością w celu podnoszenia jakości ich życia”"

Skrajnie odmienne, tj. czysto egoistyczne i pragmatyczne, definicje idei CSR lansowane są z kolei w pracach przedstawicieli nauk o zarządzaniu oraz wśród menedżerów. Tu społeczna odpowiedzialność biznesu rozumiana jest jako innowacyjny, zinstytucjonalizowany i zracjonalizowany element przemyślanej strategii działania przedsiębiorstwa, który w perspektywie długofalowej może stać się waż-

${ }^{7}$ Por. M. Bojar, op. cit., s. 13.

${ }^{8}$ Zob. F. P. Seitel, Public Relations w praktyce, Wydawnictwo Felberg SJA, Warszawa 2004, s. 91.

${ }^{9}$ K. Kietliński, V. M. Reyez, T. Oleksyn, Etyka w biznesie i zarzadzaniu, Oficyna Ekonomiczna, Kraków 2005, s. 132. 
nym źródłem przewagi konkurencyjnej ${ }^{10}$, lub jako „strategia budowania dobrych relacji z otoczeniem, co znajduje swoje odzwierciedlenie w sukcesie ekonomicznym przedsiębiorstwa"11. Takie spojrzenie na idę CSR bliższe jest raczej koncepcji tzw. marketingu zaangażowanego społecznie ${ }^{12}$ i wyrachowanym działaniom typu PR aniżeli zagadnieniom etycznego biznesu. W tym znaczeniu społeczna odpowiedzialność przedsiębiorstw staje się tylko "chwytliwą” marketingową deklaracją, „ładną etykietką” i środkiem do maksymalizacji skalkulowanego zysku firmy.

Przedstawione powyżej, skrajnie różne postrzeganie koncepcji społecznej odpowiedzialności biznesu budzi liczne obiekcje autorki. Wątpliwości te wynikają przede wszystkim $\mathrm{z}$ obserwacji, zgodnie $\mathrm{z}$ którymi przedsiębiorstwo nie może stać się totalnym altruistą finansującym społeczne projekty (gdyż w ten sposób sprzeniewierzyłoby swój kapitał i upadło) ani też nie powinno realizować jedynie swoich egoistycznych celów kosztem otoczenia (gdyż zostałoby wyeliminowane z rynku). Właściwe byłoby natomiast poszukiwanie rozwiązań korzystnych dla wszystkich, czyli zgodnie z zadeklarowanym celem artykułu, ukazanie współczesnej idei CSR jako strategii umożliwiającej wzrost konkurencyjności firmy oraz realizację i wzmacnianie jej ekonomicznych funkcji, przy jednoczesnym zaangażowaniu przedsiębiorstwa w sprawy społeczne.

Dlatego też, na potrzeby niniejszego artykułu, została opracowana własna, szeroka definicja społecznej odpowiedzialności biznesu, zgodnie z którą CSR jest długofalową, dobrowolną strategią przemyślanego i etycznego kształtowania relacji ze wszystkimi interesariuszami, opartą na zasadach dialogu społecznego, oraz koncepcją zarządzania, w której firma podejmuje takie decyzje i działania, które z jednej strony przyczyniają się do dbałości o interes własny przedsiębiorstwa (tj. trwałe pomnażanie zysku, powiększanie przewagi konkurencyjnej, poprawianie wizerunku rynkowego itp.), z drugiej zaś prowadzą do ochrony i pomnażania dobrobytu społecznego (zarówno w obszarze poszanowania praw człowieka, warunków pracy i interesów społeczności lokalnych, jak również ochrony środowiska naturalnego $)^{13}$. Należy przy tym podkreślić, iż tak rozumiana społeczna odpowie-

${ }^{10} \mathrm{Na}$ podstawie J. Nakonieczna, Spoteczna odpowiedzialnośc przedsiębiorstw międzynarodowych, Difin, Warszawa 2008, s. 20; M. E. Porter, M. R. Kramer, The Competitive Advantage of Corporate Philanthropy, „Harvard Business Review on Corporate Responsibility”, Harvard Business School Press 2003.

${ }^{11}$ B. Rok (red.), Więcej niż zysk, czyli odpowiedzialny biznes. Programy, strategie, standardy, Forum Odpowiedzialnego Biznesu, Warszawa 2001, s. 32.

${ }^{12}$ Szerzej na temat marketingu zaangażowanego społecznie (ang. Cause Related Marketing, w skrócie CRM) A. M. Stafiej-Bartosik, Danone-spotecznie zaangażowany, „Marketing w Praktyce", luty 2007, nr 2 (108), s. 24-26; L. Sparks, Efektywna sprzedaż. 151 btyskotliwych rozwiazań, Wydawnictwo ONE Press, 10/2008, s. 50-52.

${ }^{13}$ Por. W. Gasparski, Wyktady z etyki biznesu, Wydawnictwo Wyższej Szkoły Przedsiębiorczości i Zarządzania im. Leona Koźmińskiego, Warszawa 2004, s. 404; B. Rok, Odpowiedzialny 
dzialność biznesu nie może ograniczać się jedynie do spełniania obligatoryjnych wymogów formalno prawnych, ale przede wszystkim musi oznaczać aktywne, niczym nieprzymuszone, społeczne zaangażowanie firm ${ }^{14}$.

\section{OBSZARY I TYPY SPOŁECZNEJ ODPOWIEDZIALNOŚCI BIZNESU}

W codziennej praktyce gospodarczej ten mieszany, tj. filantropijno-egoistyczny, charakter koncepcji etycznego biznesu przejawia się w trzech podstawowych obszarach odpowiedzialności, tj. w sferze ekonomicznej, społecznej i ekologicznej (patrz schemat 1).

Wdrażanie przez przedsiębiorstwo zasad CSR w obszarze ekonomii rozpoczyna się już na etapie produkcji, kiedy to firma decyduje się na wytwarzanie produktów i opakowań bezpiecznych dla konsumentów i środowiska naturalnego, deklaruje pełną zgodność dóbr i usług z normami, przestrzega surowych standardów oraz w sposób systematyczny i ciągły monitoruje wpływ swego funkcjonowania na otoczenie społeczne i przyrodnicze. Dla ekonomii etycznego biznesu szczególne znaczenie mają działania przedsiębiorstwa związane z zarządzaniem zasobami ludzkimi. W tym zakresie firmy legitymujące się mianem społecznie odpowiedzialnych powinny stosować politykę równości szans, zapewniać sprawiedliwe płace, wdrażać programy i kodeksy etyczne, szkolić swoją kadrę, jak również zachęcać do partycypacji pracowniczej. Coraz częściej dostrzegalne jest nawet oferowanie swym pracownikom dodatkowych form opieki zdrowotnej i zabezpieczeń socjalnych, wspieranie ich w godzeniu obowiązków rodzinnych $\mathrm{z}$ pracą zawodową, a także - w przypadku restrukturyzacji czy masowych zwolnień - stosowanie polityki outplacementu i minimalizowanie negatywnych skutków dla zwalnianych i ich rodzin. $Z$ kolei dla interesariuszy przedsiębiorstwa najlepiej widoczne będą etyczne zachowania firmy w zakresie szeroko rozumianego marketingu, a więc udział w różnego rodzaju akcjach charytatywnych, edukacyjnych, kulturalnych, sportowych i proekologicznych, sponsoring, zarządzanie relacjami z klientami i dostawcami ( $\mathrm{w}$ tym przede wszystkim budowanie więzi lojalnościowych), uczciwe konkurowanie, rzetelne rozpatrywanie reklamacji oraz stosowanie przejrzystych zasad nadzoru korporacyjnego ${ }^{15}$. Z omówionym tu ob-

biznes w nieodpowiedzialnym świecie, Akademia Rozwoju Filantropii w Polsce, Forum Odpowiedzialnego Biznesu, Warszawa 2004, s. 18-19; Green Paper. Promoting a European Framework for Corporate Social Responsibility, Bruksela, 18.07.2001, s. 6-8.

${ }^{14} \mathrm{~W}$ dalszej części artykułu społeczna odpowiedzialność biznesu rozumiana będzie zgodnie z przedstawioną autorską definicją.

${ }^{15} \mathrm{Na}$ podstawie M. Szczepański, Spoteczna odpowiedzialnośc biznesu jako element strategii zarzadzania reputacja firmy, [w:] M. Bojar (red.), Spoteczna odpowiedzialność w biznesie, Wydawnictwo Politechniki Lubelskiej, Lublin 2007, s. 21-22; B. Rok, Odpowiedzialny biznes..., s. 20-21. 
szarem ekonomicznym wiążą się przede wszystkim takie specjalizacje społecznie odpowiedzialnego biznesu, jak CSR systemowy i rynkowy ${ }^{16}$.

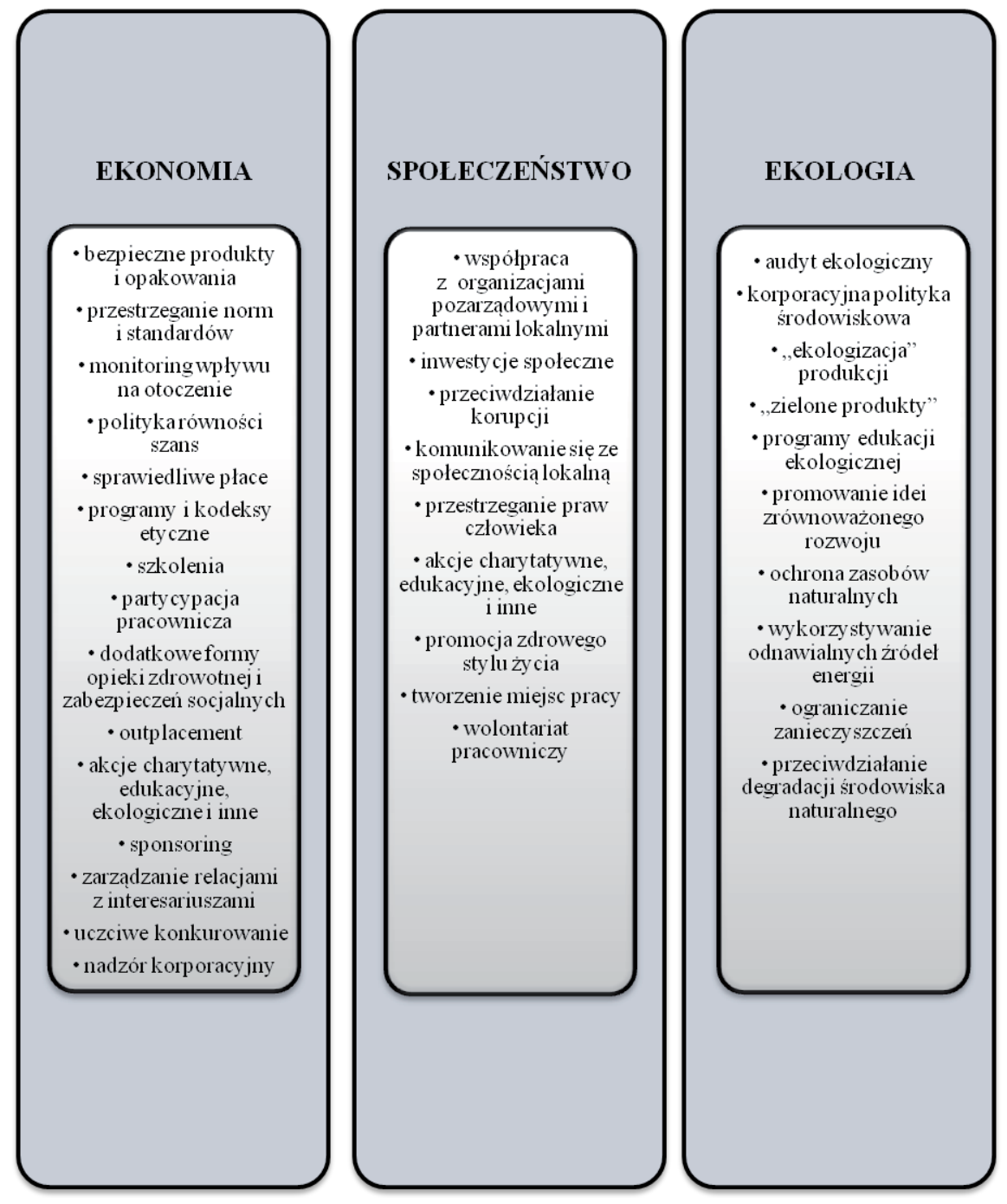

Schemat 1. Obszary i typy społecznej odpowiedzialności biznesu

Źródło: opracowanie własne.

${ }^{16}$ Szerzej na temat CSR systemowego i rynkowego B. Rok, Jaki to byt rok dla odpowiedzialnego biznesu?, Raport „Odpowiedzialny biznes w Polsce 2007. Dobre praktyki”, Forum Odpowiedzialnego Biznesu, Warszawa 2008, s. 5-6. 
Z kolei w sferze społecznej wyróżnić można CSR społeczny i publiczny ${ }^{17}$, rozciągający się od codziennej, z dobrego serca płynącej filantropii, aż po najbardziej innowacyjne, poważne projekty partnerstwa prywatno-społecznego lub publiczno-prywatnego. Dla tego obszaru szczególnie istotne jest podejmowanie przez przedsiębiorstwo społecznie odpowiedzialne współpracy z organizacjami pozarządowymi i partnerami lokalnymi, dokonywanie inwestycji społecznych, przeciwdziałanie korupcji, a także respektowanie praw i zwyczajów społeczności lokalnej oraz przestrzeganie praw człowieka. Dodatkowo, częścią wspólną dla sfery społecznej i ekonomicznej CSR może być zaangażowanie firm w akcje charytatywne, o charakterze edukacyjnym i ekologicznym oraz związane $z$ zachowaniem dziedzictwa kulturowego, promowanie zdrowego stylu życia, jak również tworzenie miejsc pracy dla osób niepełnosprawnych i po pięćdziesiątym roku życia oraz wolontariat pracowniczy ${ }^{18}$.

Niewątpliwie najbardziej rozpoznawalnym obszarem koncepcji społecznie odpowiedzialnego biznesu jest sfera ekologii i związany z nią CSR ekologiczny ${ }^{19}$. W tej dziedzinie przedsiębiorstwa społecznie odpowiedzialne przede wszystkim realizują specjalne programy zarządzania wpływem na środowisko naturalne, których elementami są m.in. audyt ekologiczny, korporacyjna polityka środowiskowa, „ekologizacja” procesów produkcyjnych czy też wytwarzanie „zielonych produktów”. CSR ekologiczny równie często wychodzi na zewnątrz firmy, czego przejawem jest udział przedsiębiorstw w programach edukacji ekologicznej, kampaniach promujących ideę zrównoważonego rozwoju, a także w akcjach zachęcających do ochrony zasobów naturalnych, wykorzystywania odnawialnych źródeł energii oraz ograniczania zanieczyszczeń i degradacji środowiska przyrodniczego ${ }^{20}$.

\section{KORZYŚCI WYNIKAJĄCE ZE STOSOWANIA STRATEGII SPOŁECZNEJ ODPOWIEDZIALNOŚCI BIZNESU}

Społeczna odpowiedzialność biznesu, a mówiąc dokładniej - związane z nią działania (opisane we wcześniejszej części artykułu), wymaga sporych nakładów finansowych, rzeczowych, ludzkich, czasowych i innych, a ponadto znacznie komplikuje proces podejmowania strategicznych dla przedsiębiorstwa decyzji. $Z$ tego

\footnotetext{
${ }^{17}$ Szerzej na temat CSR społecznego i publicznego B. Rok, Jaki to byt rok..., s. 4-6.

${ }^{18} \mathrm{Na}$ podstawie G. Enderle, Global competition and corporate responsibilities of small and medium-sized enterprises, „Business Ethics: A European Review”, January 2004, vol. 12, no. 1, s. 54; J. Nakonieczna, op. cit., s. 70-72; B. Rok, Odpowiedzialny biznes..., s. 12-13 oraz 20-21.

${ }^{19}$ Szerzej na temat CSR ekologicznego B. Rok, Jaki to byt rok..., s. 6.

${ }^{20} \mathrm{Na}$ podstawie G. Enderle, op. cit., s. 54; J. Nakonieczna, op. cit., s. 76-79; B. Rok, Odpowiedzialny biznes..., s. 12-13 oraz 20-21.
} 
też powodu wdrażanie przez firmy zasad CSR postrzegane jest niekiedy - mylnie - tylko jako dodatkowy koszt, zmniejszający efektywność ekonomiczną prowadzonej działalności gospodarczej. Niemniej jednak społeczna odpowiedzialność biznesu powinna być rozpatrywana $\mathrm{w}$ kategoriach opłacalnej inwestycji, gdyż w średnim i długim okresie (a czasami nawet już w krótkim) przynosi ona liczne korzyści, zarówno samemu przedsiębiorstwu, jak i jego interesariuszom. Przykłady takich korzyści zilustrowano na schemacie 2 .

\section{KORZYŚCI DLA INTERESARIUSZY}

Zgodnie z zaprezentowanym poniżej schematem pierwsze i bezpośrednie korzyści, wynikające z realizacji przez przedsiębiorstwo strategii CSR, osiągają interesariusze. Jedną z najważniejszych jest fakt, iż firmy, wspierając lub co więcej inicjując programy i kampanie społeczne, przyczyniają się do nagłośnienia konkretnych problemów (np. niedożywienie dzieci, przemoc w rodzinie, narkomania, dyskryminacja kobiet) i zachęcają do stawienia czoła tym negatywnym zjawiskom. To z kolei prowadzi do znacznego ograniczenia skali zwalczanych problemów, a nawet do ich całkowitej eliminacji. Nie mniej istotna jest profilaktyka i próba zdławienia pewnych patologii już w zarodku. Dlatego też społecznie odpowiedzialne przedsiębiorstwa coraz częściej angażują się w akcje edukacyjne, dzięki którym interesariusze wyposażeni zostają w wiedzę na temat zdrowego stylu życia i prawidłowego odżywiania się, praw człowieka, dziecka czy obywatela lub z zakresu etyki biznesu ${ }^{21}$.

Kolejnym pożytkiem dla społeczeństwa jest ukształtowanie dzięki strategiom CSR aktywnych postaw proekologicznych oraz wzrost poziomu świadomości ekologicznej, zarówno u dzieci i młodzieży, jak również u dorosłych. Efekt ten osiągany jest poprzez wdrażanie przez społecznie odpowiedzialne firmy wewnętrznych polityk środowiskowych oraz dzięki organizacji kampanii zachęcających do ochrony zasobów naturalnych i promujących ideę zrównoważonego rozwoju 22 .

Realizacja przez przedsiębiorstwa zasad etycznego biznesu przynosi także liczne korzyści ich pracownikom, konsumentom i kontrahentom. Pracownicy społecznie odpowiedzialnych firm mogą cieszyć się zdecydowanie lepszymi warunkami pracy, sprawiedliwymi płacami oraz rozszerzonymi systemami opieki zdrowotnej i zabezpieczeń socjalnych. $Z$ kolei klienci tych przedsiębiorstw mogą mieć pewność, że nabywane przez nich produkty są bezpieczne w użytkowaniu, wysokiej jakości i coraz bardziej dostosowane do potrzeb rynku. Natomiast

${ }^{21} \mathrm{Na}$ podstawie Przeglad CSR - Danone PL, Warszawa 2006, s. 22-34; B. Rok, Odpowiedzialny biznes..., s. 56.

${ }^{22}$ Zob. Przeglad CSR..., s. 36-40; B. Rok, Odpowiedzialny biznes..., s. 56. 
pożytki dla kontrahentów etycznych firm wynikają z dostępu do wiarygodnych informacji, które przedsiębiorstwa stosujące w praktyce zasady CSR publikują $\mathrm{w}$ formie raportów społecznych, sprawozdań z zewnętrznego audytu lub wyników badań w sferze ekonomicznej, społecznej i ekologicznejej .

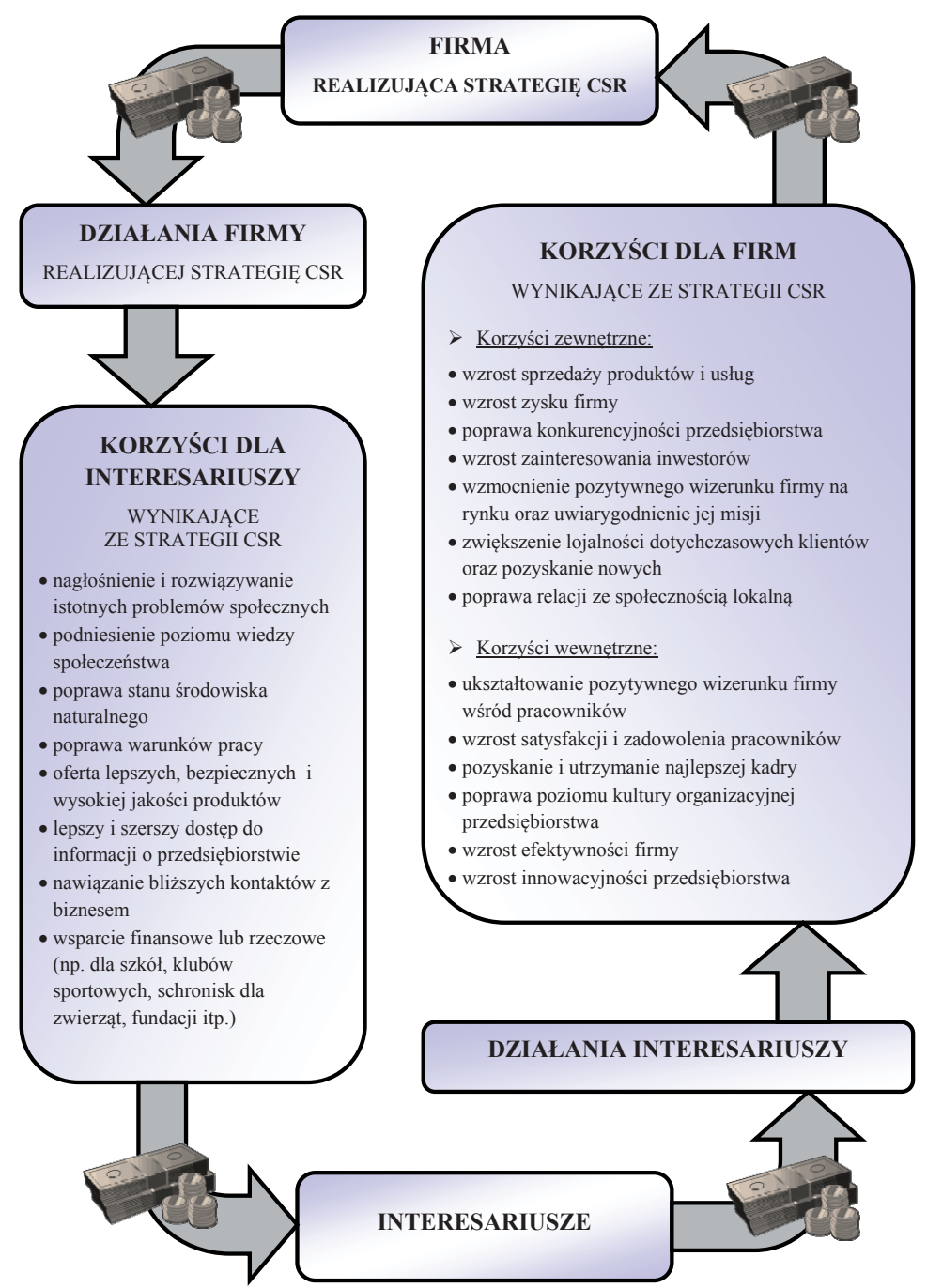

Schemat 2. Korzyści wynikające ze stosowania strategii społecznej odpowiedzialności biznesu Źródło: opracowanie własne.

${ }^{23}$ Na podstawie Przeglad CSR..., s. 8-20; B. Rok, Odpowiedzialny biznes..., s. 56. 
$\mathrm{Na}$ uwagę zasługuje także fakt, że społecznie odpowiedzialny biznes dodatkowo przyczynia się do nawiązywania nowych lub zacieśniania istniejących kontaktów na linii przedsiębiorstwo-partner społeczny bądź przedsiębiorstwo-partner publiczny, nierzadko wzmocnionych wkładem finansowym lub rzeczowym firmy. Pielęgnowanie tych więzi i czerpanie z nich wymiernych profitów jest szczególnie ważne dla takich podmiotów, jak szkoły, domy dziecka, kluby sportowe, schroniska dla zwierząt, fundacje, stowarzyszenia i inne organizacje pożytku publicznego ${ }^{24}$.

\section{KORZYŚCI DLA PRZEDSIĘBIORSTWA}

Kontynuując analizę przedstawionego wcześniej schematu 2, łatwo dostrzec, że jeszcze bogatszy zestaw profitów z tytułu stosowania strategii społecznej odpowiedzialności biznesu osiąga przedsiębiorstwo. Efekty te można podzielić na zewnętrzne (tj. związane $z$ otoczeniem firmy) oraz wewnętrzne ( $\mathrm{tj}$. dotyczące relacji wewnątrz organizacji).

Najbardziej widoczną dla przedsiębiorstwa korzyścią zewnętrzną, wynikającą ze stosowania przez nie strategii CSR, jest ułatwiony dostęp do nowych kanałów zbytu oraz systematyczny wzrost sprzedaży produktów i usług, nierzadko przy jednoczesnej redukcji kosztów działalności. W długim okresie rosnące obroty społecznie odpowiedzialnych firm przekładają się na zwiększenie ich zysków, poprawę ogólnej sytuacji finansowej oraz podwyższenie wartości przedsiębiorstwa, a w przypadku spółek giełdowych - również na stabilny wzrost wartości ich akcji. Należy przy tym wspomnieć, że zaangażowanie firm w różnego rodzaju działania społeczne czy ekologiczne może być także skutecznym sposobem uzyskiwania wartości dodanej przedsiębiorstwa i znacznej poprawy jego konkurencyjności na rynku ${ }^{25}$.

Kolejnym, prezentowanym na schemacie 2, profitem zewnętrznym dla organizacji wdrażającej zasady CSR jest wzrost zainteresowania inwestorów i co za tym idzie, łatwiejszy dostęp do finansowania swojej działalności biznesowej. Wynika to $\mathrm{z}$ faktu, iż kredytodawcy są bardziej skłonni do współpracy z firmami, które poza dbałością o dobre wyniki finansowe, dodatkowo troszczą się o akceptację społeczną i nieskazitelny wizerunek, są zarządzane w sposób transparentny oraz budują nienaganne relacje ze swoimi interesariuszami. B. Rok twierdzi nawet, że „dla wielu inwestorów wiarygodność finansowa firmy jest ściśle uzależniona od jej wiarygodności społecznej”26.

${ }^{24}$ Szerzej na ten temat w Przeglad CSR..., s. 44-54.

${ }^{25} \mathrm{Na}$ podstawie H. Białoń, R. Kołodziej, Zyski z CSR, „Marketing w Praktyce”, lipiec 2008, nr 7 (125), s. 70.

${ }^{26}$ B. Rok, Odpowiedzialny biznes..., s. 54 . 
Bardziej „miękkim”, choć równie ważnym efektem zewnętrznym jest postrzeganie przedsiębiorstw społecznie odpowiedzialnych jako tych, które zachowują się w sposób etyczny, są wiarygodne i przyjazne środowisku oraz posiadają własną silną tożsamość. Prowadzi to do wzmocnienia pozytywnego wizerunku tych firm, znacznego zwiększenia ich rozpoznawalności oraz uwiarygodnienia misji przedsiębiorstwa w oczach jego klientów i kontrahentów.

Dobra reputacja organizacji stosujących zasady CSR wspomaga także procesy budowania zaufania do odpowiedzialnych marek, wzmacnia stosunki lojalnościowe $z$ dotychczasowymi nabywcami i wspiera pozyskiwanie nowych ${ }^{27}$. Dodatkowo kształtowanie „ludzkiej twarzy biznesu” i podejmowanie długofalowych inwestycji społecznych umożliwia firmie bezkonfliktowe funkcjonowanie w społeczności lokalnej, pomaga pozyskać przychylność i poparcie jej mieszkańców oraz poprawia relacje przedsiębiorstwa $z$ władzami samorządowymi, co może mieć szczególne znaczenie w przypadku pojawienia się kryzysu lub innych zagrożeńn ${ }^{28}$.

Nie mniej istotne są korzyści wewnętrzne, jakie firma może czerpać ze stosowania strategii CSR. Gros z nich dotyczy relacji przedsiębiorstwa z jego pracownikami.

Coraz wyraźniej dostrzega się, że kadry społecznie odpowiedzialnych organizacji pozytywnie oceniają wizerunek swojej firmy, z większym uznaniem odnoszą się do jej funkcjonowania oraz darzą ją dużym szacunkiem i zaufaniem, co przekłada się na wzrost satysfakcji i zadowolenia $\mathrm{z}$ tytułu wykonywanych obowiązków. Ponadto, widząc, że część aktywności organizacji skupiona jest na wspieraniu społeczności lokalnej, z którą pracownicy firmy solidaryzują się, kadra odczuwa dodatkową motywację do wytężonych wysiłków na rzecz przedsiębiorstwa ${ }^{29}$.

Co szczególnie ważne, wymienione tu czynniki sprawiają, że pracownicy firm wdrażających zasady CSR w większym stopniu identyfikują się ze swoim przedsiębiorstwem i są wobec niego lojalni, przez co społecznie odpowiedzialne organizacje mają duże szanse na zatrzymanie najlepszych specjalistów, jak również wyraźne perspektywy na pozyskanie doświadczonej kadry od konkurencji, i to bez konieczności znacznej podwyżki stawki wynagrodzenia ${ }^{30}$.

Wśród efektów wewnętrznych na uwagę zasługuje także fakt, że zmiany, które zachodzą w firmach stosujących strategię CSR, wpływają dodatkowo na

\footnotetext{
${ }^{27} \mathrm{Na}$ podstawie E. Hoinkis, Pozytywne aspekty stosowania strategii spotecznej odpowiedzialności w przedsiębiorstwie, [w:] H. Howaniec, W. Waszkielewicz, Wspótczesne problemy zarzadzania przedsiębiorstwami w gospodarce rynkowej, Wydawnictwo Akademii Techniczno-Humanistycznej, Bielsko-Biała 2008, s. 211.

${ }^{28}$ Zob. B. Rok, Odpowiedzialny biznes..., s. 54.

${ }^{29}$ Por. E. Hoinkis, op. cit., s. 212; B. Rok, Odpowiedzialny biznes..., s. 55.

${ }^{30}$ Zob. H. Białoń, R. Kołodziej, op. cit., s. 72.
} 
podniesienie poziomu kultury organizacyjnej, wzrost efektywności i poprawę innowacyjności przedsiębiorstwa ${ }^{31}$.

\section{ZAGROŻENIA WYNIKAJĄCE Z WYPACZANIA IDEI SPOŁECZNEJ ODPOWIEDZIALNOŚCI BIZNESU}

Ten bardzo pozytywny, wręcz sielankowy, obraz idei CSR, przedstawiony we wcześniejszych częściach niniejszego artykułu, w praktyce bywa niestety wypaczany przez przedsiębiorstwa, które, szczycąc się mianem społecznie odpowiedzialnych, jednocześnie podejmują działania daleko odbiegające od standardów odpowiedzialności, moralności, rzetelności i uczciwości. W firmach tych strategie społecznego zaangażowania, deklarowana wrażliwość na bolączki współczesnego świata i realizacja różnego rodzaju programów pomocowych wykorzystywane są często jedynie w celu „lukrowania”, czy wręcz tuszowania niewygodnych faktów. Jest to szczególnie znamienne w przypadku przedsiębiorstw działających w branżach związanych z produkcją i sprzedażą wyrobów tytoniowych, alkoholi, kosmetyków czy farmaceutyków, gdzie gołym okiem widoczna jest przepaść między korporacyjną, czysto PR-owską retoryką a prawdziwym obliczem organizacji ${ }^{32}$. Takie instrumentalne i wyrachowane posługiwanie się ideą CSR sprawia, że koncepcja ta (pomimo licznych korzyści zarówno dla samych przedsiębiorstw, jak i ich interesariuszy) wciąż budzi liczne kontrowersje, wątpliwości i nieufność otoczenia, a tym samym deprecjonuje nawet najbardziej szczytne cele realizowane przez organizacje w pełni zasługujące na miano społecznie odpowiedzialnych.

Jest i druga strona medalu. Strategie CSR są także - choć zdecydowanie rzadziej - wypaczane poprzez zbyt altruistyczne podejście do idei społecznie odpowiedzialnego biznesu. Dzieje się tak wówczas, gdy przedsiębiorstwa przeznaczają na swą misję etycznego biznesu relatywnie zbyt wysokie kwoty, a tym samym naruszają interesy właścicieli i sprzeniewierzają majątek firmy. Takie działania choć podejmowane ze szlachetnych pobudek - mogą być interpretowane jako działanie na szkodę organizacji i pociągać za sobą skutki karne ${ }^{33}$.

${ }^{31}$ Szerzej na ten temat B. Rok, Odpowiedzialny biznes..., s. 55.

${ }^{32} \mathrm{Na}$ podstawie Spoteczna odpowiedzialność przedsiębiorstw - narzędzie PR czy coś więcej?, artykuł został przedstawiony na konferencji „Etyka w życiu gospodarczym” w Salezjańskiej Wyższej Szkole Ekonomii i Zarządzania w Łodzi 12 maja 2005 r., https://www.studiumpr.pl:448/node/155 (26.05.2010).

${ }^{33} \mathrm{Na}$ podstawie A. D. Nowicka, Czy CSR to tylko PR? Polemika, Forum Odpowiedzialnego Biznesu, 24 marca 2010. 
Wynika z tego, że w biznesie społecznie odpowiedzialnym - jak i w każdej innej dziedzinie gospodarowania - należałoby znaleźć „złoty środek” między czystym altruizmem a skrajnym egoizmem.

\section{ZAKOŃCZENIE}

Rosnąca popularność idei społecznej odpowiedzialności biznesu, zarówno wśród teoretyków, jak i praktyków ekonomii, jest dowodem na kształtowanie się zupełnie nowego wizerunku współczesnego przedsiębiorstwa i jego roli w społeczeństwie. Zmiany te polegają przede wszystkim na szerszym spojrzeniu na cele działania firmy, które nie mogą już ograniczać się jedynie do sfery czysto ekonomicznej, ale muszą uwzględniać także (choć oczywiście $\mathrm{w}$ racjonalnych proporcjach) działalność o charakterze społecznym czy ekologicznym ${ }^{34}$, gdyż jak to trafnie ujął B. Gates: „każde przedsiębiorstwo musi realizować misję społeczną, bo tylko dzięki temu zyskuje rację istnienia" ${ }^{35}$. W tym kontekście koncepcja CSR - o ile jest poprawnie rozumiana, a nie wypaczana - pozwala organizacjom wzmacniać swoją pozycję na rynku i w społeczeństwie oraz znaleźć „złoty środek" pomiędzy totalnym egoizmem a czystym altruizmem, dając efekt w postaci wymiernych korzyści zarówno dla samej firmy, jak i jej interesariuszy. $Z$ tego też powodu w najbliższym czasie można spodziewać się, iż idea społecznej odpowiedzialności biznesu stanie się istotnym wyznacznikiem efektywnego funkcjonowania i zarządzania przedsiębiorstw.

\section{CORPORATE SOCIAL RESPONSIBILITY - BETWEEN ALTRUISM AND SELFISHNESS OF COMPANIES \\ SUMMARY}

The main target of this paper is to show the modern idea of Corporate Social Responsibility (CSR) as an effective strategy oriented to improve a company's economic performance, linked with social, charitable and environmental activity. The major points of the article are: an extended definition of the CSR idea, areas and types of this conception, connected with CSR benefits for the company and its stakeholders and strands of the CSR idea.

\footnotetext{
${ }^{34} \mathrm{Na}$ podstawie J. Nakonieczna, op. cit., s. 220.

${ }^{35}$ Cyt. za: B. Rok, Jaki to byt rok..., s. 6.
} 
